\title{
STUDY HABITS AND LEARNING STYLES OF VOCATIONAL STUDENTS IN THE EFL LEARNING CONTEXT
}

\author{
N.K.A. Sudianthi ${ }^{1}$, M.H. Santosa ${ }^{2}$, N.L.P.E.S. Dewi ${ }^{3}$ \\ ${ }^{123}$ English Language Education, Universitas Pendidikan Ganesha, Singaraja \\ e-mail: ayusudianthi@gmail.com, mhssantosa@undiksha.ac.id, sulistia.dewi@undiksha.ac.id
}

\begin{abstract}
This study aimed to identify study habits during the online learning and face to face learning, the dominant learning styles of the students, find out whether there are differences of study habits in online learning and face-to-face learning, the association between learning styles and study habits, and the constraints of EFL students to have good study habits in online learning. The design of the study was embedded mix method research design. The sample of the study was 205 students in Hotel Department in SMKN 4 Denpasar who were chosen randomly. The data were collected by using close-ended and open-ended questionnaires. The result of the study showed that there were differences between study habits in online learning and face-to-face learning. In online learning, students had moderate study habits, while in face-to-face learning they had good study habits. The dominant learning styles were kinaesthetic and there were low associations between learning styles and study habits. The were some constraints to have good study habits from parents, teacher, students and school.
\end{abstract}

\section{Keywords: Constraints; Learning Styles; Online Learning; Study Habits}

\section{INTRODUCTION}

Study habits are the core of the success in academic. Learning to study effectively and have a good study habits will lead the students to be able to work effectively. By having good study habits, students can improve their critical thinking, time management, work preparation, memorizing ability and also health management There are some factors that impact the study habits of the students. Khan (2016) found that gender, economic status and learning styles have significant impact in study habits of the students. Study habits refer to the way of the students in studying and students' usual act in the learning process (Ayodele \& Adebiyi, 2013; Proctor et al., 2006). A systematic, effective, and efficient study habit will imply positive academic performance. Otherwise, ineffective, and inefficient study habits will produce negative academic performance. Good study habits provide a high score in English achievement; meanwhile, poor study habits provide a low score in students' achievement. Good study habits will lead them to work effectively, because it will make them accustomed to work effectively and efficiently (Barrass, 2002). Having good study habits are important for the students especially for Vocational High School students in Hotel Department. Mahbub (2019) stated that students in hotel department should have a particular skill to be professional worker in specific field to be ready to compete in workplace. The employees in tourism industry should fulfill some requirements and skills to be a professional hotelier. To be a professional hotelier, students should have good study habits in time budgeting, taking note ability, reading ability, memorizing ability, good health, studying based on the learning styles and learning motivation (Khursid, 2012; Kiblasan, 2016; Magulod, 2019; Sabbah, 2016).

According to Palsane \& Sharma (1989), there are eight dimensions in identifying the study habits of students. They are 1) Time Budgeting, (2) Physical condition, (3) reading ability, (4) note-taking, (5) learning motivation, (6) Memorization, (7) taking examination, (8) health.

There are some factors that impact the study habits of the students. Kiblasan (2016); Mohit, (2019) found that gender, economic status, year level and learning styles have significant impact in study habits of the students. Learning styles are the various ways of learning to absorb the material efficiently. Some students prefer to read a book and memorize the material, on the other hand some students need to take some notes to help 
them to understand the material. The other students feel more enjoyable watching the video of tutorial to do something rather than reading the manual book (Aboe, 2019). There are some learning habits inventory used in previous research. One of the most common used is widely known as VARK learning styles (Fleming, 2012). VARK learning style is used to measure the individual style in learning. VARK is the acronym of Visual (V), Aural (A), ReadWrite $(\mathrm{R})$, and Kinesthetic $(\mathrm{K})$.

Due to pandemic COVID-19, the learning process should be done at home through internet connections which is called as online learning (Idrizi et al., 2018). The government changed face-to-face learning into online learning. On the other hand, some problems occurred during the online learning such as motivation, self-discipline, time management, connection problems, lack of interaction and discussion with teacher and friends, feeling stress, and do not understand the lesson (Adnan, 2020; Gilbert et al., 2015; Khan et al., 2017). Considering the problem in online learning, having good study habits and be aware with the learning styles preferences may affect the achievement of the students during the online learning. Therefore, the researcher is interested to identify the study habits of the students during the online learning and face-to-face learning and compare the result. Moreover, the purposes of this research are also to identify the dominant learning styles, and find out whether any association between learning styles and study habits, and also the constraints of the students in having good study habits during the online learning.

\section{RESEARCH METHOD}

The sample of this research was 205 students of Hotel Department students in SMKN 4 Denpasar. This research study used embedded mixed method design due to it combines quantitative and qualitative design. Quantitative research used descriptive inferential design (Creswell, 2012). Descriptive research was used to identify the study habits of the students in online learning and face-to-face learning and also the dominant learning styles of the students. While inferential design was used to find out whether any differences between study habits exhibited by the students in online learning and face-to-face learning and also to find out if there was any association between learning styles and study habits. Furthermore, qualitative research was used to identify the constraints of the students in having good study habits during the online learning.

The data was collected by adopting Palsane and Sharma Study Habits Inventory (PSSHI) from Palsane \& Sharma (1989) which consisted of 45 statements which were divided into 8 dimensions. They are 1) Time Budgeting, (2) Physical condition, (3) reading ability, (4) note-taking, (5) learning motivation, (6) Memorization, (7) taking examination, (8) health. There were 3 choices in every statement. Always or often rated 2, sometimes rated 1 , and rarely or never rated 0 . The range of the score was $0-90.0-30$ which was categorized as poor study habits, 31-60 as moderate study habits, and 61-90 as good study habits. In order to identify the dominant learning styles, the data was collected by adapting questionnaires from VARK questionnaire version 8.1 which consisted of 16 questions with four choices that described their style in learning. Students chose one option which represented their learning. Both of the questionnaires were translated into Indonesian version. To analyze the constraints of the students to have a good study habits through online learning was measured by using open-ended questionnaires. There were 16 questions which involved eight dimensions of Palsane and Sharma Study Habits Inventory (PSSHI). In order to compare the study habits of the students in online learning and face-to-face learning, SPSS 26 was applied. To determine the association of learning styles and study habits, Cramer's V correlation was applied due to the data was in nominal and ordinal scale. The range of the data association was 0 to 1 . The score 0 means there was no association and 1 means it was a strong association. The Hyphothesis of this research was there were differences of study habits exhibited by the students in online learning and face-to-face learning, moreover there was association of learning styles and study habits of students. 


\section{FINDINGS AND DISCUSSION}

\section{a. The Study Habits of the Students in Online Learning}

Table 1. The Result Of Descriptive Statitical Analysis

\begin{tabular}{|c|c|c|c|c|c|}
\hline & & Frequency & Percent & $\begin{array}{c}\text { Valid } \\
\text { Percent }\end{array}$ & $\begin{array}{l}\text { Cumulativ } \\
\text { e Percent }\end{array}$ \\
\hline \multirow{4}{*}{ Valid } & Good Study Habits & 34 & 16.6 & 16.6 & 16.6 \\
\hline & Moderate Study Habits & 167 & 81.5 & 81.5 & 98.0 \\
\hline & Poor Study Habits & 4 & 2.0 & 2.0 & 100.0 \\
\hline & Total & 205 & 100.0 & 100.0 & \\
\hline
\end{tabular}

Table 1 showed $16.6 \%$ of students had good study habits, $81.5 \%$ of studntents had moderate study habits, while $2 \%$ of the students had poor study habits. It can be stated that most of the students had moderate study habits during the online learning.

Table 2. The Percentage For Each Dimension

\begin{tabular}{clccc}
\hline No & \multicolumn{1}{c}{ Dimensions } & $\begin{array}{c}\text { Good Study } \\
\text { Habits }\end{array}$ & $\begin{array}{c}\text { Moderate } \\
\text { Study Habits }\end{array}$ & Poor Study Habits \\
\hline I & Time budgeting & $35.9 \%$ & $51.7 \%$ & $12.5 \%$ \\
II & Physical condition & $34.2 \%$ & $50.8 \%$ & $15.0 \%$ \\
III & Reading Ability & $35.1 \%$ & $52.1 \%$ & $12.7 \%$ \\
IV & Note taking & $22.9 \%$ & $63.6 \%$ & $13.5 \%$ \\
V & Learning Motivation & $45.4 \%$ & $42.7 \%$ & $12.0 \%$ \\
VI & Memory & $37.1 \%$ & $49.5 \%$ & $13.4 \%$ \\
VII & Taking Examination & $35.5 \%$ & $50.5 \%$ & $14.0 \%$ \\
VII & Health & $34.1 \%$ & $57.6 \%$ & $8.3 \%$ \\
\hline
\end{tabular}

In table 2, it can be seen that from eight dimensions in PSHHI, seven dimensions were in moderate study habits level, while only one dimension was in good study habits. It concluded that the students need improvement in time budgeting, physical condition, reading ability, note taking, memory, taking examinantion and health dimension.

\section{b. The Study Habits of Students in Face-to-Face Learning}

Table 3. The Result of Descriptive Statitical Analysis

\begin{tabular}{|c|c|c|c|c|c|}
\hline & & Frequency & Percent & $\begin{array}{c}\text { Valid } \\
\text { Percent }\end{array}$ & $\begin{array}{l}\text { Cumulative } \\
\text { Percent }\end{array}$ \\
\hline & Good Study Habits & 128 & 62.4 & 62.4 & 62.4 \\
\hline Valid & $\begin{array}{c}\text { Moderate Study Habits } \\
\text { Total }\end{array}$ & $\begin{array}{l}77 \\
205\end{array}$ & $\begin{array}{c}37.6 \\
100.0\end{array}$ & $\begin{array}{l}37.6 \\
100.0\end{array}$ & 100.0 \\
\hline
\end{tabular}

Table 3 showed $62.4 \%$ of students had good study habits, $37.6 \%$ of studntents had moderate study habits, and no students had poor study habits. It can be stated that most of the students had good study habits during the online learning.

Table 4. The Percentage For Each Dimension

\begin{tabular}{clccc}
\hline No & Dimensions & $\begin{array}{c}\text { Good Study } \\
\text { Habits }\end{array}$ & $\begin{array}{c}\text { Percentage } \\
\text { Moderate }\end{array}$ & Poor Study Habits \\
\hline I & Time budgeting & $68.3 \%$ & $29.1 \%$ & $2.6 \%$ \\
II & Physical condition & $56.3 \%$ & $36.1 \%$ & $7.9 \%$ \\
III & Reading Ability & $44.6 \%$ & $47.5 \%$ & $7.9 \%$ \\
\hline
\end{tabular}




\begin{tabular}{cllll}
\hline IV & Note taking & $43.9 \%$ & $47.6 \%$ & $8.5 \%$ \\
V & Learning Motivation & $57.2 \%$ & $37.3 \%$ & $5.4 \%$ \\
VI & Memory & $55.9 \%$ & $40.2 \%$ & $3.9 \%$ \\
VII & Taking Examination & $51.6 \%$ & $39.4 \%$ & $9.0 \%$ \\
VII & Health & $56.3 \%$ & $37.8 \%$ & $5.9 \%$ \\
\hline
\end{tabular}

In table 4, it can be seen that from eight dimensions in PSHHI, six dimensions were in good study habits level, while two dimensions were in good study habits. It is concluded that the students need improvement in reading ability and note-taking dimensions.

\section{c. The Dominant Learning Styles of the Students}

Table 5. The Result of Descriptive Statitical Analysis

\begin{tabular}{|c|c|c|c|c|c|}
\hline & & & Le & ng Styles & \\
\hline & & Frequency & Percent & Valid Percent & Cumulative Percent \\
\hline & Visual & 43 & 21.0 & 21.0 & 21.0 \\
\hline & Aural & 62 & 30.2 & 30.2 & 51.2 \\
\hline Valid & Read-Write & 18 & 8.8 & 8.8 & 60.0 \\
\hline & Kinesthetic & 82 & 40.0 & 40.0 & 100.0 \\
\hline & Total & 205 & 100.0 & 100.0 & \\
\hline
\end{tabular}

Table 5 showed that 43 students or $21 \%$ of students had visual learning styles, while 62 students or $30.2 \%$ of students had aural learning styles. Moreover, 18 students or $8.8 \%$ had read-write learning styles and 82 students or $40 \%$ of students had Kinesthetic learning styles. Therefore, the dominant learning styles was kinesthetic learning styles.

\section{d. The Comparison of Study Habits in Online Learning and Face to Face Learning}

In order to find out whether any differences between study habits in online learning and face to face learning, Paired T-Test was conducted.

Table 6. The Mean Comparison

\begin{tabular}{llcccc}
\hline \multicolumn{5}{c}{ Paired Samples Statistics } \\
& Mean & N & Std. Deviation & Std. Error Mean \\
\hline \multirow{2}{*}{ Pair 1 Study Habits Online } & 53.83 & 205 & 10.296 & .719 \\
& Study Habits Face-to-face & 64.20 & 205 & 10.096 & .705 \\
\hline
\end{tabular}

There were differences between the mean in online learning and face-to-face learning. Study habits through online learning showed 53.83 while study habits during faceto-face learning showed 64.20. Therefore, the mean of study habits during face-to-face learning was higher than through online learning.

Table 7. Paired Sample Test

\section{Paired Samples Test}

Paired Differences

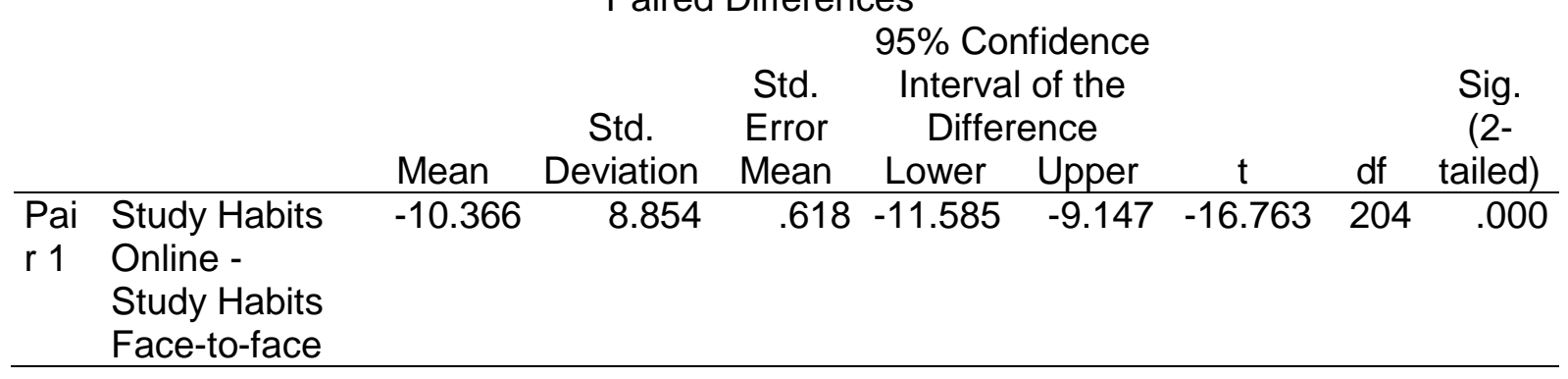

To determine the significant difference between the data, it can also be seen from the Sig (2-tailed) value. If the Sig (2-tailed) value is greater than 0.005 , it means that there is no significant difference between the data. On the other hand, if the Sig (2-tailed) value is less 
than 0.05 , there is a significant difference between the data. The Sig (2-tailed) value in Table 6 showed 0.000 . It can be concluded that there were significant differences of study habits exhibited by the students through online learning and face-to-face learning.

\section{e. The Association of Learning Styles to Study Habits in Online Learning}

Table 7. The Result Of The Cramer'V Association

\begin{tabular}{llcc}
\hline & \multicolumn{3}{c}{ Symmetric Measures } \\
\hline & & Value & Approximate Significance \\
Nominal by & Phi & .182 & .338 \\
Nominal & Cramer's V & .129 & .338 \\
N of Valid Cases & & 205 & \\
\hline
\end{tabular}

As seen in table 7, the approximate significance of association between learning styles and study habits of EFL students during the online learning showed 0.338 . According to association degree interval by Anwar (2009), it can be categorized that there was a positive association between learning styles and study habits. If the range association is in range $0.20-0.399$, it can be categorized as low association. Therefore, it can be concluded that learning styles had low association to study habits of students.

\section{f. The Constraints in Having Good Study Habits in Online Learning}

Table 8. The Percentage of Constraints

\begin{tabular}{ccc}
\hline No & Dimension of Study Habits & Percentage of constraints \\
\hline 1 & Time Budgeting & $47.75 \%$ \\
2 & Physical Condition & $23.45 \%$ \\
3 & Reading ability & $38.15 \%$ \\
4 & Note-taking & $36.20 \%$ \\
5 & Learning motivation & $45.45 \%$ \\
6 & Memory & $59.30 \%$ \\
7 & Taking examination & $31.90 \%$ \\
8 & Health & $28.20 \%$ \\
\hline
\end{tabular}

Table 9. The Students Contrainst

\begin{tabular}{ll}
\hline Dimensions & \multicolumn{1}{c}{ The constraints } \\
\hline Time & gangguan sinyal, keterbatasan kuota, jam pelajaran terkadang tidak \\
Budgeting & sesuai \\
& Hp saya suka macet, jadi kadang saat daring suka lemot \\
& Karena kebanyakan yg saya dapatkan adalah tugas saja dengan \\
& deadline yg lumayan singkat. Sedikit guru yg mendiskusikan materinya. \\
& Daring membuat saya lebih bersemangat membuka sosmed dan \\
& youtube daripada membuka file materi. \\
Physical & Orang tua saya sibuk bekerja, jadi saya belajar sendiri dan mengajari \\
Condition & adik saya belajar juga \\
& Karena setiap saya belajar di ganggu dan di bilang main hp saja padahal \\
Reading & ngerjain tugas \\
Ability & Membuat Cepat Jenuh \\
& Karena saya bosan kebanyakan membaca tulisa polos yang diberikan \\
& oleh guru, agar tidak bosan bolehlah ditambahin tema/template, animasi \\
dill. & Karena biasanya saya simpah di hand phone saja \\
kearning & karena materinya ada di google \\
Motivation & guru yang memberikan penjelasan tapi susah untuk dimengerti
\end{tabular}




\begin{tabular}{ll}
\hline & Karena orang tua saya sibuk, semuanya diserahkan ke diri saya. Kalau \\
Memory & $\begin{array}{l}\text { Saya belajar yaudah, kalau gak belajar yaudah. } \\
\text { Saya termasuk susah untuk mengafalkan atau mengingat sesuatu atau } \\
\text { materi }\end{array}$ \\
& $\begin{array}{l}\text { Penyebab bagi saya adalah saya cukup sulit dalam menghafal, } \\
\text { penyebab lainnya adalah situasi dirumah yang selalu ramai dan tidak }\end{array}$ \\
& ada tempat sunyi untuk menghafal \\
Taking & Karena saya melihat buku atau mencontek teman \\
Examination & kita bisa mendapatkan jawabn melalui internet \\
Health & Merasa stress karena Kurangnya penjelasan, banyak tugas dan malu \\
& bertanya \\
& Terlalu lama online membuat mata saya berair dan cepat pusing. \\
\hline
\end{tabular}

Table 8 showed the percentage of the constraints of the students in online learning. Memory dimension showed the highest percentage of constraints, while the lowest percentage of constraints was physical condition dimension. In Table 9 there were the constraints of the students during the online learning. The constraints were unstable of internet connection, lack of internet data, not compatible devices, easily distracted by social media, unsupported study environment at home also became the constraints in online learning. In addition, the constraints in reading ability were easy to be bored and monotonous display of the books. In note taking, students thought that the material has been kept in their handphone so they did not take a note of the material and also, they could search it in Google, just typed the keywords and they got the answer. The constraints in learning motivation such as they did not understand the teacher's exlplanation, and also there wass no support from their parents at home because their parents worked. In memory dimension, the constraints such as they could not memorize the material easily, their houses were often noisy and crowded, so it was difficult for them to concentrate in memorizing the material. In taking examinantion, the constraints were that they could search in the internet, ask their friends, see in the book because there was no supervision from the teacher. The constraints in health dimension were those like they felt stress because of lack of explanation, too many assignmnets, embarrassed to ask. Moreover, students felt dizzy and got eyestrains when they had to see the device for long time.

As seen in research finding, there were differences between study habits exhibited by the students in online learning and face-to-face learning. In online learning students had moderate study habits in seven dimensions in PSSHI. Time budgeting, physical condition, reading ability, note taking, memory, taking examination and health. All of dimensions need to improve with the support from the students, teachers, parents and school.

Online learning brings many challenges for some students to have good study habits. Agung \& Surtikanti (2020) found some challenges in online learning such as the sustainability and availability of the internet connection, the accessibility of the teaching media and the compatible device to acess the platform. These challenges can affect the study habits of students. For instance, when students want to study ontime, then the internet connection is not stable, it will waste longer time to do it. When the students have to read the material online, then the device is not compatible, it also affects the study habits of the students. It will decrease their motivation in learning. Hand (2018) found that online learning arises some problems related to health of the students. Online learning leads to anxiety and stress. When the students meet problems and they do not understand the material, they need discussion and interaction with their teachers and their friends. However, during the online learning, it is difficult to do and it makes the students stressed and anxious. While doing the assignment, they may skip their eating and sleeping schedule. Students who have poor study habits often do the assignment a few hours before the due date, and it will force them to stay awake until midnight. Their physical health is also at risk due to the overusing of the device. During the online learning, students use the computer for more than 6 hours a day to follow the online learning and do the assignments. Eyestrains, joint muscles, headache may happen during the online learning. 
In order to overcome the problems that affected the study habits of the online learning, all of the stakeholders in education process such as teachers, parents, school and government should work together to get the solution of these problems. Teacher can make variation in teaching media and strategies so that the lesson will be more interesting. Teacher should accommodate the students and have good interactions during the online learning. Hearing the students' problems and try to find the solutions together with their parents can help to motivate them in online learning. Parents can support the online learning by providing their children the facilities such as devices, internet data, calm and light environment. To improve the ability in reading and note taking, teacher can ask the students to read the material and then take note for the important point and then have discussion with them through learning Platform. Taking examination during the online learning can be so tricky for the students. Without supervising from their teacher and parents, it is easy for them to open the note, search in Google or ask their friends. To avoid these problems, teacher can give them the authentic assessment to evaluate their achievement. For instance, making the video, project-based assessment that they can do at home.

During face-to-face learning, students exhibited good study habits. From eight dimensions, six dimensions showed good study habits, while two dimensions reading ability and note taking dimension showed moderate study habits. There were many aspects that impact the study habits of students in face-to-face learning. In time budgeting dimension, during face-to-face learning, students should follow school regulation everyday. They have a regular schedule that they should follow, consequently they know, what time they should study and take a rest. It also influences their health. They usually wake up early in the morning, take a nap in the afternoon and sleep well at night. The school environment should also support the learning process. At school they can study in calm environment and easy to concentrate. They listen, discuss, and study freely without being disturbed with the internet connection and signal. Students are also more motivated when they can discuss with their friends and see their friends' progress. It will motivate them to study better than before. The moderate of study habits in reading ability and taking note dimensions happen because some students do not like reading and also write something. It can be caused by the learning styles of the students. As the research finding only $8.8 \%$ of students as the sample have read-write learning styles. It also proved that learning styles affect study habits. Teacher can improve the students in reading ability by asking the students to read any kind of book that they are interested in and share what they have read to their friends.

The dominant learning styles was kinesthetic learning styles. Students with kinesthetic learning styles process information through touching, moving and doing. They can learn effectively if they can move their body or interact with the environment. They learn through demonstration, simulation, tutorial video, field trip, do things practically, laboratory, practical lesson and hands-on approach. The kinesthetic students prefer to be active learners rather than passive learners. They have active gestures when talking, they learnt by seeing other people do the same thing. They prefer trial and error, practice it until they get how to make it rather than learn the theory. Due to their experience, they are good in problem solving and practical problems. It is in line with the characteristics of Vocational school, which have $70 \%$ of the lessons need to be practiced. Therefore, the students get used to do practical lesson. Vocational education is practical, experiential, hands-on, contextual learning in order to prepare them to be a professional in the workplace (Erdem, 2019). The teacher's strategies in teaching kinesthetic students such as create the physical activities such as dancing, folding, role playing, performing drama, etc. Moreover, to engage the kinesthetic students during the online learning, teacher should balance the theory and practice. Teachers can make interactive learning such as interactive games, demonstrate the material, give the practical assignment, and simulations (McQuillan, 2017).

As stated in research finding, there was a low correlation between learning styles and study habits of EFL students during the online learning. It means that learning styles have association to the study habits of EFL students but not significant. It does not mean that one learning style will have good study habits, and other learning styles may have moderate or poor study habits. The study habits of EFL students during the online learning can be influenced by other aspects. As previous research finding, there were many challenges during the online learning such as the internet connection, study environment, gender, socio- 
economic status, and family background.

The constraints of students of Hotel Department in having good study habits during the online learning were the unstable of internet connections, lack of internet data, unsupported devices, did not understand the lesson, unsupported environment, not used to read in electronic device, less interaction with the teacher and friends, and no supervision from the teacher on examination, so the students did not prepare the test as well as face-toface learning and also see the computer or mobile phone screen made them dizzy, got eyestraint and joint muscle. It is in line with the research finding from Agung \& Surtikanti (2020); Gilbert (2015).

As the result of the study, it can be concluded that study habits of the students of Hotel Department in SMKN 4 Denpasar in face-to-face learning were better than in online learning. Kinesthetic learning styles as the dominant learning styles of the students also have association with study habits but not significant. There were some constraints of the students in having good study habits in online learning, such as the unstable of internet connections, lack of internet data, unsupported devices, did not understand the lesson, unsupported environment, not used to read in electronic device, less interaction with the teacher and friends, and no supervision from the teacher on examination, so the students did not prepare the test as well as face-to-face learning and also see the computer or mobile phone screen made them dizzy, got eyestraint and joint muscle.

It is suggested to the students to provide themselves with high bandwidth or strong internet connection that on-line courses require, and thus succeed to catch up with virtual leanings or limit the technical issues. Parents are suggested to support their children at home, by providing the facilities, comfortable study environment, and accompany their children when they meet problems during the online learning. Teachers are suggested to vary their teaching methods, strategies, and media related the dominant learning styles of the students. Teachers are suggested to have active interaction and good communication with students, parents and other teachers to solve the problems that occur during the online learning. School is suggested to have an information center in assisting teachers and students with the problems regarding the online learning.

\section{CONCLUSION AND SUGGESTIONS}

The present research studied the study habits exhibited by the student in online learning and face-to-face learning, the learning styles of the students, the comparison between the study habits, the association of learning styles and study habits and the constraints of EFL students to have good study habits during the online learning. The research was designed using a Mixed Method Research, both quantitative and qualitative design. The data were collected by using four instruments. The type of quantitative research in this study was a descriptive inferential research design. Descriptive quantitative design used to identify the study habits and learning styles of EFL students. Inferential design used to analyze the difference of study habits during the online learning and the association of learning styles and study habits. While, qualitative design used to identify the constraints of the students to have good study habits during the online learning.

The study habits exhibited by the study habits of the students of Hotel Department in SMKN 4 Denpasar in face-to-face learning were good while in online learning the study habits were moderate. It means, there were significant differences between study habits in online learning and face-to-face learning. Kinesthetic learning styles as the dominant learning styles of the students also have association with study habits but not significant. There was low association between learning styles and study habits. There were some constraints of the students in having good study habits in online learning. Such as the unstable of internet connections, lack of internet data, unsupported devices, did not understand the lesson, unsupported environment, not used to read in electronic device, less interaction with the teacher and friends, and no supervision from the teacher on examination, so the students did not prepare the test as well as face-to-face learning and also see the computer or mobile phone screen made them dizzy, got eyestraint and joint muscle. 


\section{REFERENCES}

Aboe, R. (2019). Correlation Between Students Learning Styles and Their Learning Achievement. Journal of Khairun University, January.

Adnan, M. (2020). Online learning amid the COVID-19 pandemic: Students perspectives. Journal of Pedagogical Research. https://doi.org/10.33902/jpsp.2020261309

Agung, A. S. N., \& Surtikanti, M. W. (2020). Students' Perception of Online Learning during COVID-19 Pandemic: A Case Study on the English Students of STKIP Pamane Talino. SOSHUM: Jurnal Sosial Dan Humaniora. https://doi.org/10.31940/soshum.v10i2.1316

Anwar, A. (2009). Statistika Untuk Penelitian Pendidikan. In IAIT Press (Vol. 53, Issue 9).

Barrass, R. (2002). Study! A Guide to Effective Learning, Revision and Examination Techniques (2nd Edition). Routledge, New York.

Creswell, J. W. (2012). Educational research: Planning, conducting, and evaluating quantitative and qualitative research. In Educational Research. https://doi.org/10.1017/CBO9781107415324.004

Erdem, S. (2019). Sarıkaya Erdem_Yıldırım_2019_Effective teaching and learning at vocational education at tertiary level.pdf. II.

Fleming. (2012). How Do I Learn Best? a Student's Guide to Improved LearFleming, N \&ning.

Gilbert, B. (2015). Online Learning Revealing the Benefits and Challenges. Fisher Digital Publications Education.

Gilbert, B., John, S., \& College, F. (2015). Online Learning Revealing the Benefits and Challenges How has open access to Fisher Digital Publications benefited you?

Idrizi, E., Filiposka, S., \& Trajkovik, V. (2018). VARK Learning Styles and Online Education: Case Study. September. https://www.researchgate.net/publication/327869001

Khan, A., Egbue, O., Palkie, B., \& Madden, J. (2017). Active learning: Engaging students to maximize learning in an online course. Electronic Journal of E-Learning.

Khan, Z. N. (2016). Factors Effecting on Study Habits. World Journal of Educational Research, 3(1), 145-150.

Khursid, et al. (2012). Relationship between Study Habits and Academic Achievement among Hostel Living and Day Scholars' University Students. British Journal of Humanities and Social Sciences January 2012, Vol. 3 (2) 34, 3(January), 34-42.

Kiblasan, et al. (2016). Analyzing the learning style and study habit of students in the faculty of nursing Analyzing the learning style and study habit of students in the faculty of nursing of Al Jabal Al Gharbi. Clinical Nursing Studies, 4(2), 48-56. https://doi.org/10.5430/cns.v4n2p48

Magulod, C. . (2019). Learning Styles, Study Habits and Academic Performance of Filipino University Students in Applied Science Courses : Implications for Instructions. Journal of Technology and Science Education, 9(2), 184-198. http://www.jotse.org/index.php/jotse/article/view/504

Mahbub, M. A. (2019). English Teaching in Vocational High School: a Need Analysis. JEELS (Journal of English Education and Linguistics Studies), 5(2), 229-258. https://doi.org/10.30762/jeels.v5i2.835

McQuillan. (2017). Facilitating the learning process of kinesthetic learners in the online environment.

Https://Wikieducator.Org/. https://wikieducator.org/Facilitating_the_learning_process_of_kinesthetic_learners_in _the_online_environment

Mohit, B. (2019). The Relationship between Study Skills and Learning Styles: The Case of 
Underachieving Students in Some Selected Secondary Schools in Wolaita, Ethiopia. IOSR Journal Of Humanities And Social Science (IOSR-JHSS), 24(3), 41-48. https://doi.org/10.9790/0837-2403084148

Palsane, M. N., \& Sharma, S. (1989). A consumable booklet of SHI (English Version). In National Psychological Corporation.

Sabbah, S. S. (2016). The Effect of Study Habits on English Language Achievement. Arab World English Journal (AWEJ), 7(4), 238-257. 